\title{
Can we predict the duration of an interglacial?
}

\author{
P. C. Tzedakis ${ }^{1}$, E. W. Wolff ${ }^{2}$, L. C. Skinner ${ }^{3}$, V. Brovkin ${ }^{4}$, D. A. Hodell ${ }^{3}$, J. F. McManus ${ }^{5}$, and D. Raynaud ${ }^{6}$ \\ ${ }^{1}$ Environmental Change Research Centre, Department of Geography, University College London, London WC1E 6BT, UK \\ ${ }^{2}$ British Antarctic Survey, Madingley Road, High Cross, Cambridge CB3 OET, UK \\ ${ }^{3}$ Department of Earth Sciences, University of Cambridge, Cambridge CB2 3EQ, UK \\ ${ }^{4}$ Max Planck Institute for Meteorology, 20146 Hamburg, Germany \\ ${ }^{5}$ Lamont-Doherty Earth Observatory, Columbia University, Palisades, NY 10964-8000, USA \\ ${ }^{6}$ Laboratoire de Glaciologie et Géophysique de l'Environnement (LGGE), CNRS - Université Joseph Fourier, Grenoble, \\ 38402 St Martin d'Hères, France
}

Correspondence to: P. C. Tzedakis (p.c.tzedakis@ucl.ac.uk)

Received: 7 March 2012 - Published in Clim. Past Discuss.: 2 April 2012

Revised: 20 August 2012 - Accepted: 30 August 2012 - Published: 24 September 2012

\begin{abstract}
Differences in the duration of interglacials have long been apparent in palaeoclimate records of the Late and Middle Pleistocene. However, a systematic evaluation of such differences has been hampered by the lack of a metric that can be applied consistently through time and by difficulties in separating the local from the global component in various proxies. This, in turn, means that a theoretical framework with predictive power for interglacial duration has remained elusive. Here we propose that the interval between the terminal oscillation of the bipolar seesaw and three thousand years (kyr) before its first major reactivation provides an estimate that approximates the length of the sea-level highstand, a measure of interglacial duration. We apply this concept to interglacials of the last $800 \mathrm{kyr}$ by using a recentlyconstructed record of interhemispheric variability. The onset of interglacials occurs within $2 \mathrm{kyr}$ of the boreal summer insolation maximum/precession minimum and is consistent with the canonical view of Milankovitch forcing pacing the broad timing of interglacials. Glacial inception always takes place when obliquity is decreasing and never after the obliquity minimum. The phasing of precession and obliquity appears to influence the persistence of interglacial conditions over one or two insolation peaks, leading to shorter $(\sim 13 \mathrm{kyr})$ and longer $(\sim 28 \mathrm{kyr})$ interglacials. Glacial inception occurs approximately $10 \mathrm{kyr}$ after peak interglacial conditions in temperature and $\mathrm{CO}_{2}$, representing a characteristic timescale of interglacial decline. Second-order differences in duration may be a function of stochasticity in the climate system, or small variations in background climate state and
\end{abstract}

the magnitude of feedbacks and mechanisms contributing to glacial inception, and as such, difficult to predict. On the other hand, the broad duration of an interglacial may be determined by the phasing of astronomical parameters and the history of insolation, rather than the instantaneous forcing strength at inception.

\section{Defining interglacial duration}

Interglacials may be characterized by any property that changes significantly on glacial-interglacial timescales - for example, temperature, atmospheric $\mathrm{CO}_{2}$ concentration, faunal or floral composition. More formally, interglacials (or interglaciations) have been defined as episodes during which global climate was incompatible with the wide extent of glaciers (American Commission on Stratigraphic Nomenclature, 1961). Thus, the fundamental concept underlying the terminology of an interglacial is that of the sea-level highstand, a measure of integrated global climate effects, which lead to the loss of continental ice. By extension, interglacial length is linked to the duration of the highstand, demarcated by deglaciation and glacial inception. A broad distinction between shorter (approximately half a precession cycle) and longer (approximately half an obliquity cycle or more) interglacials has been recognized (e.g. Shackleton, 1969; EPICA community members, 2004; Tzedakis et al., 2009), although closer inspection has hinted at considerable variation in specific durations (e.g. Forsström, 2001; Tzedakis et al., 2004). 
Accounting for such differences can provide insights into climate forcings and feedbacks that are relevant to the onset and end of interglacials. A more general motivation is to consider whether the duration of interglacials obeys some simple rules or whether it is essentially unpredictable because of stochasticity in the climate system and small differences in background climate state.

To pursue this question the timing of sea-level changes needs to be constrained, but direct sea-level determinations supported by precise geochronological dating are unavailable for most Middle Pleistocene interglacials. The $\delta^{18} \mathrm{O}$ from benthic foraminifera may be used as a sea-level proxy, but is overprinted by local deep-water temperature and hydrographic effects, especially near inflection points in the $\delta^{18} \mathrm{O}$ curve (e.g. Chappell and Shackleton, 1986; Skinner and Shackleton, 2005). In addition, the $\delta^{18} \mathrm{O}$ of seawater $\left(\delta^{18} \mathrm{O}_{\mathrm{sw}}\right)$ is relatively insensitive during glacial inception because early ice is less depleted in ${ }^{16} \mathrm{O}$ than ice accumulated later in the glacial cycle (Mix and Ruddiman, 1984). A record using shallow-infaunal benthic foraminifera to deconvolve deep-water temperatures and $\delta^{18} \mathrm{O}_{\mathrm{sw}}$ over the last $1.5 \mathrm{mil}$ lion years has recently become available from the ODP site 1123 on the Chatham Rise, east of New Zealand (Elderfield et al., 2012). With hydrographic effects considered minimal at this site, the $\delta^{18} \mathrm{O}_{\text {sw }}$ provides an important insight into icevolume changes over this interval, but the propagated error of $\pm 0.2 \%$ in calculated $\delta^{18} \mathrm{O}_{\mathrm{sw}}$ ( $\pm 20 \mathrm{~m}$ sea-level-equivalent), estimated by Elderfield et al. (2012), is too coarse to allow a precise demarcation of the onset and end of the sealevel highstand at the scale of individual interglacials. A continuous sea-level reconstruction based on planktonic $\delta^{18} \mathrm{O}$ records and a hydrological model for the Red Sea is available for the last $520 \mathrm{kyr}$ (Rohling et al., 2009), but it is unclear whether the sea-level component has been entirely isolated. Comparison with direct sea-level determinations from Marine Isotope Stage (MIS) 5 (Thompson and Goldstein, 2006) shows that the Red Sea record does well in estimating the height of the highstand, but less well in inferring the timing of glacial inception, with short peaks followed by early sealevel declines. The modelled sea-level curve by Bintanja and van de Wal (2008) extends over the last 3 million years, but depends on assumptions about deep-water temperatures and their coupling with atmospheric temperatures. Interglacial duration in this record would thus reflect the model's prior assumptions.

Whereas pinpointing the start and end of the highstand in convolved sea-level proxy records is not straightforward, an indication of the presence of ice sheets can be provided by the occurrence of interhemispheric millennial-scale climate variability. This requires ice sheets large enough to extend to coastlines and produce iceberg discharges that disrupt the meridional overturning circulation (MOC), leading to rapid cooling of the North Atlantic and gradual warming of Antarctica. This asynchronous phasing in temperatures can be explained by a bipolar-seesaw mechanism (Stocker and Johnsen, 2003), whereby changes in the strength of the MOC lead to changes in interhemispheric heat transport. An asymmetric response has also been observed in North Atlantic cores on the Portuguese margin (Shackleton et al., 2000; Margari et al., 2010) and the Gardar Drift (Hodell et al., 2010), where $\delta^{18} \mathrm{O}_{\text {planktonic }}$ records resemble the Greenland temperature record, reflecting rapid migration of the polar front (Shackleton et al., 2000), whereas $\delta^{18} \mathrm{O}_{\text {benthic }}$ curves resemble the Antarctic temperature record, both in shape and phasing relative to surface-water changes. This primarily reflects changes in local deep-water $\delta^{18} \mathrm{O}_{\mathrm{dw}}$, a significant portion of which is attributed to changes in deep-water sourcing and/or source signature (Skinner et al., 2007).

We propose that the interval between the "terminal" oscillation of the bipolar seesaw, preceding an interglacial, and its first major reactivation represents a period of minimum extension of ice sheets away from coastlines. Given that the response of the MOC and the strength of the bipolar seesaw may be modulated by different boundary conditions (e.g. Green et al., 2010; Margari et al., 2010), it is conceivable that a non-active bipolar seesaw might not necessarily indicate interglacial conditions (false-negative) or that an active bipolar seesaw might not indicate glacial conditions (false-positive). With respect to the former, however, a terminal oscillation of the bipolar seesaw appears to be a characteristic feature of deglaciation (e.g. Cheng et al., 2009; Ganopolski and Roche, 2009; Barker et al., 2011). With respect to the latter, freshwater fluxes can occur within an interglacial, but are unlikely to lead to a major disruption of the MOC when the system is in a "warm circulation mode" (Ganopolski and Rahmstorf, 2001); thus, the first major reactivation of the bipolar seesaw would probably constitute an indication that the transition to a glacial state had already taken place.

The occurrence of the bipolar seesaw can be determined stratigraphically in ice cores and marine sequences, by the characteristic fingerprint of interhemispheric changes in climate and hydrographic conditions (Tzedakis et al., 2012). The current and last interglacials provide a test of this approach. The onset of the current interglacial (Fig. 1) is placed at the end of the Younger Dryas stadial, representing an interruption of the deglaciation process, with glacial readvances in some regions and a reduction in the rate of sea-level rise (Bard et al., 2010). The Younger Dryas also represents the last significant bipolar-seesaw oscillation, when temperatures rose in Antarctica, while the North Atlantic cooled. This definition of the interglacial onset excludes a large part of the early Antarctic warming and may, at first glance, appear North Atlantic-centric. However, given that major ice sheets were located around this region, a North Atlanticbased interglacial definition, for example using the increase in Greenland temperatures, is not entirely at odds with the concept of the sea-level highstand. In a similar vein, the end of terminal Heinrich Event 11 defines the onset of the Last Interglacial, which excludes the early Antarctic warming, but includes the peak in $\mathrm{CH}_{4}$ concentrations and the rise in 


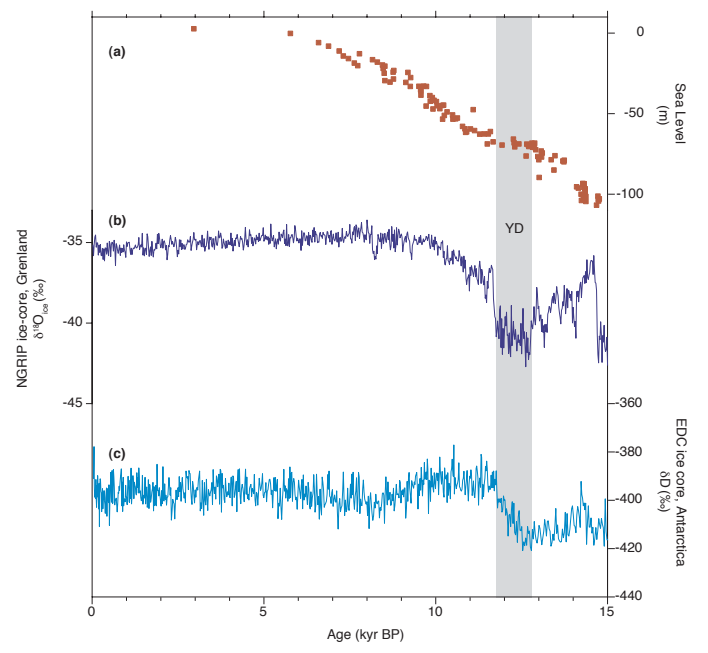

Fig. 1. Lateglacial and Holocene palaeoclimate records. (a) sealevel reconstruction (Lambeck and Chappell, 2001); (b) $\delta^{18} \mathrm{O}$ composition of ice in the NGRIP ice core, Greenland (North Greenland Ice Core Project members, 2004); (c) $\delta$ D composition of ice in the EPICA Dome C (EDC) ice core (Jouzel et al., 2007). Grey band denotes the position of the Younger Dryas (YD) stadial.

Greenland temperatures reconstructed by Barker et al. (2011) (Fig. 2). Although intra-interglacial events may have also disrupted the MOC (e.g. the " $8.2 \mathrm{kyr}$ before present [BP] event", or an event $\sim 126 \mathrm{kyr}$ BP), they do not appear to have left an unambiguous interhemispheric fingerprint in Antarctic icecore records.

With respect to the end of interglacials, the MIS 5e$5 \mathrm{~d}$ transition represents the only relevant period with direct sea-level determinations and precise chronologies that allow us to infer a sequence of events around the time of glacial inception (Fig. 2). The first major perturbation of the MOC occurred during cold-water event $\mathrm{C} 24$, characterized by abrupt surface cooling and ice rafting in the North Atlantic, and decreased Greenland temperatures, gradual decrease in $\delta^{18} \mathrm{O}_{\text {benthic }}$ values, and gradual warming in Antarctica (Shackleton et al., 2002; Oppo et al., 2006; Capron et al., 2010). The onset of these changes, $\sim 111 \mathrm{kyr} \mathrm{BP}$ according to revised estimates based on precisely dated speleothem records (Drysdale et al., 2007; Cheng et al., 2009; Barker et al., 2011), suggests that ice sheets had become large enough to calve along coastlines and disrupt the MOC. Direct sealevel determinations indicate that sea level fell $\sim 119 \mathrm{kyr}$ BP (Thompson and Goldstein, 2006), but rose again after that. Sea level started falling monotonically between 115 and $113 \mathrm{kyr} \mathrm{BP}$, reaching $20-30 \mathrm{~m}$ below present by the time of event C24 (Thompson and Goldstein, 2006). Thus, glacial inception occurred $\sim 3 \mathrm{kyr}$ before the onset of significant bipolar-seesaw variability.

The reactivation of the bipolar seesaw provides a minimum age or a "terminus ante quem" for glacial inception, which clearly had occurred sometime before. Based on the

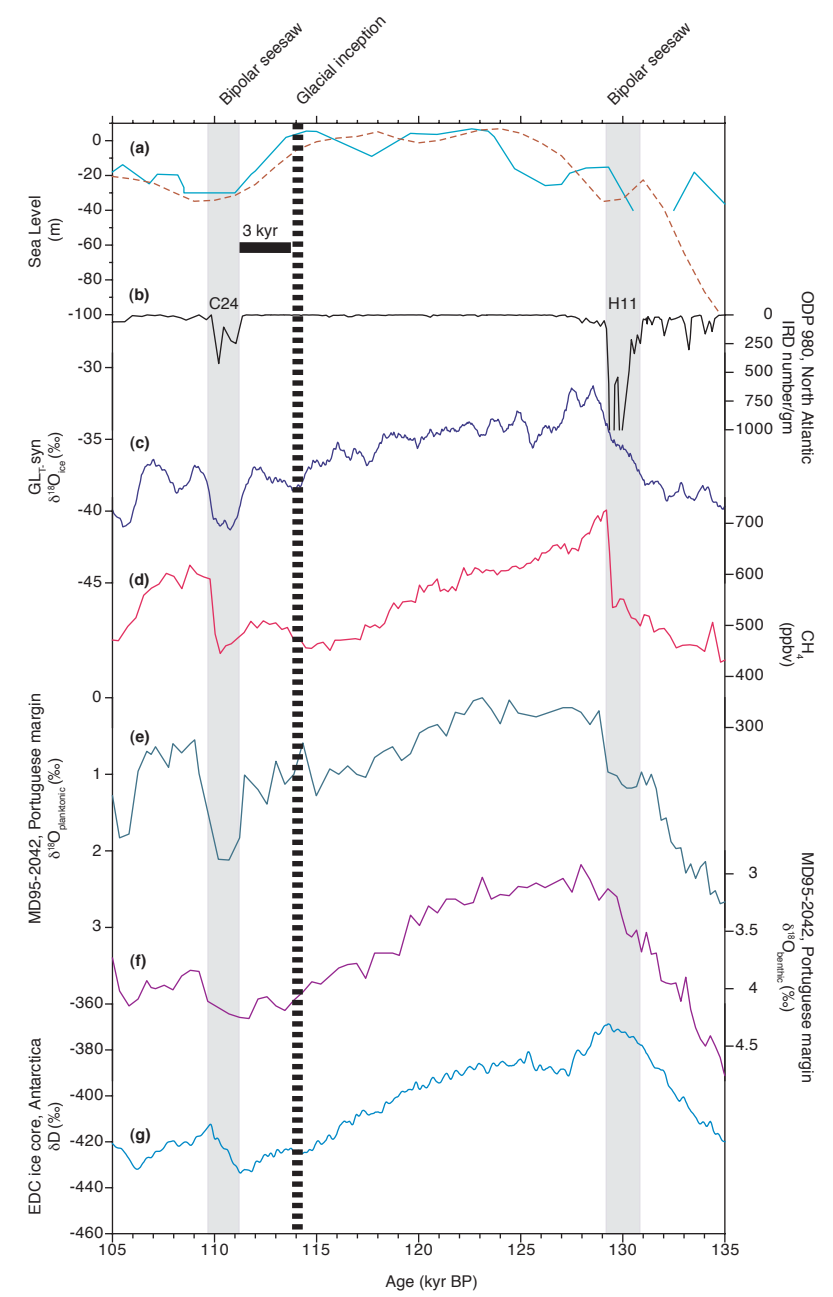

Fig. 2. Last Interglacial palaeoclimate records. (a) sea-level reconstructions by Thompson and Goldstein (2006) (continuous line) and Kopp et al. (2009) (dashed line); (b) ice rafted detritus (IRD) abundance data in Site OPD 980 in the North Atlantic (Oppo et al., 2006); (c) reconstructed $\delta^{18} \mathrm{O}$ composition of ice in Greenland synthetic $\left(\mathrm{GL}_{T-\mathrm{syn}}\right)$ record; timescale based on alignment to Chinese speleothem records (Barker et al., 2011); (d) atmospheric $\mathrm{CH}_{4}$ concentration in the EDC ice core (Loulergue et al.,

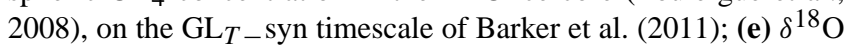
composition of planktonic foraminifera in core MD95-2042 on the Portuguese margin (Shackleton et al., 2002); timescale based on alignment of the $\delta^{18} \mathrm{O}_{\text {planktonic }}$ record to the $\mathrm{GL}_{T-\text { syn record of }}$ Barker et al. (2011); (f) $\delta^{18} \mathrm{O}$ composition of benthic foraminifera in core MD95-2042 on the Portuguese margin (Shackleton et al., 2002); timescale as in (e); (g) $\delta$ D composition of ice in the EDC ice core (Jouzel et al., 2007), on the $\mathrm{GL}_{T-\text { syn timescale of Barker }}$ et al. (2011). Grey bands denote the position of terminal Heinrich Event 11 (H11) and of cold-water event C24. Thick dashed line shows the estimated timing of the monotonic drop in sea-level on the Thompson and Goldstein (2006) chronology. 

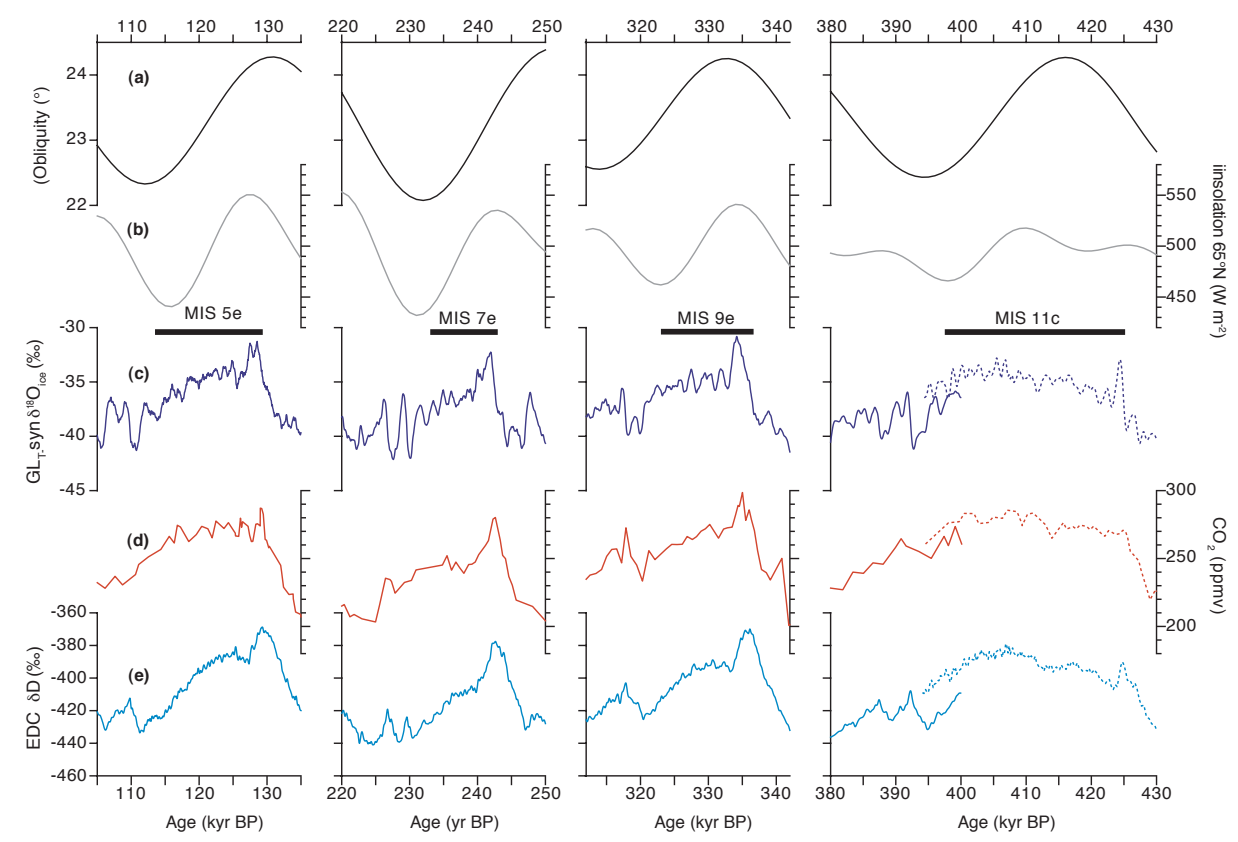

Fig. 3. Astronomical parameters and palaeoclimatic records for the interglacials corresponding to MIS 5e, 7e, 9e and 11c. Thick horizontal bands indicate estimated interglacial duration (see text). (a) obliquity (Laskar et al., 2004); (b) 21 June insolation $65^{\circ} \mathrm{N}$ (Laskar et al.,

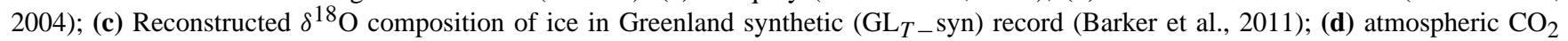
concentration in Antarctic ice cores (Lüthi et al., 2008); (e) $\delta$ D composition of ice in the EDC ice core (Jouzel et al., 2007). Palaeoclimate records from the interval $0-400 \mathrm{kyr} B \mathrm{P}$ are plotted on the $\mathrm{GL}_{T-}$ syn timescale based on alignment to Chinese speleothem records (Barker et al., 2011). As this does not extend to the base of the MIS 11c, records from the early part of the interglacial (dotted lines) are plotted on the EDC3 timescale of Parrennin et al. (2007) (see Barker et al., 2011). Thus the timing of the MIS 11c glacial inception is based on the

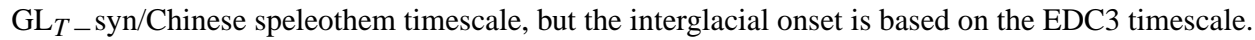

MIS 5e-5d transition, we propose to apply the same response phasing of $3 \mathrm{kyr}$ to infer the onset of glacial inception at previous interglacial-to-glacial transitions. Transient simulations with the CLIMBER-2 intermediate-complexity model with interactive ice sheets show a faster increase in inlandice area and volume at lower insolation minima compared to moderate minima (Calov et al., 2009). Given the large decrease in summer insolation over the Last Interglacial as a result of the strong eccentricity-precession forcing, we suggest that the value of $3 \mathrm{kyr}$ may be treated as a minimum. We thus estimate interglacial duration as the interval between the terminal occurrence of bipolar-seesaw variability and $3 \mathrm{kyr}$ before its first major reactivation. This fixed lag inevitably introduces a further layer of uncertainty on top of timescale errors, but on the other hand, it allows a more realistic estimate of the timing of new ice growth and an assessment of the magnitude of associated changes in forcings and feedbacks. At the other end, the placement of the interglacial onset after the terminal bipolar-seesaw oscillation does not represent the time when maximum sea level was attained, nor would it necessarily lead to the same value of relative sea level between interglacials, as rates of deglaciation may vary between terminations, depending on the location and size of ice sheets and insolation forcing (e.g. Ehlers and Gibbard,
2004; Parrenin and Paillard, 2003). Instead, it represents a time when ice sheets had retreated from the coastline and includes the early peaks in northern temperature and greenhouse gases that are part of our intuitive concept of an interglacial. It is therefore important to underline that this definition of interglacial duration is not identical to a definition based on a fixed sea-level threshold. It represents instead a "process-based" definition (relying on the operation of the bipolar seesaw in proximity to climate intervals of interest), which allows a stratigraphic delimitation of an interval approximating the length of the sea-level highstand. As such, it can be applied consistently on any interval with a sealevel highstand throughout the part of the record characterized by millennial-scale variability and circumvents difficulties of comparing periods that may not meet the conventional idea of an interglacial characterized by sea level at least as high as that of the Holocene.

\section{Applying the concept}

We determine the duration of interglacials over the last $800 \mathrm{kyr}$ (Figs. 3 and 4), for which ice-core records of atmospheric $\mathrm{CO}_{2}$ and $\mathrm{CH}_{4}$ concentrations are available (Lüthi et al., 2008; Loulergue et al., 2008), thereby providing 

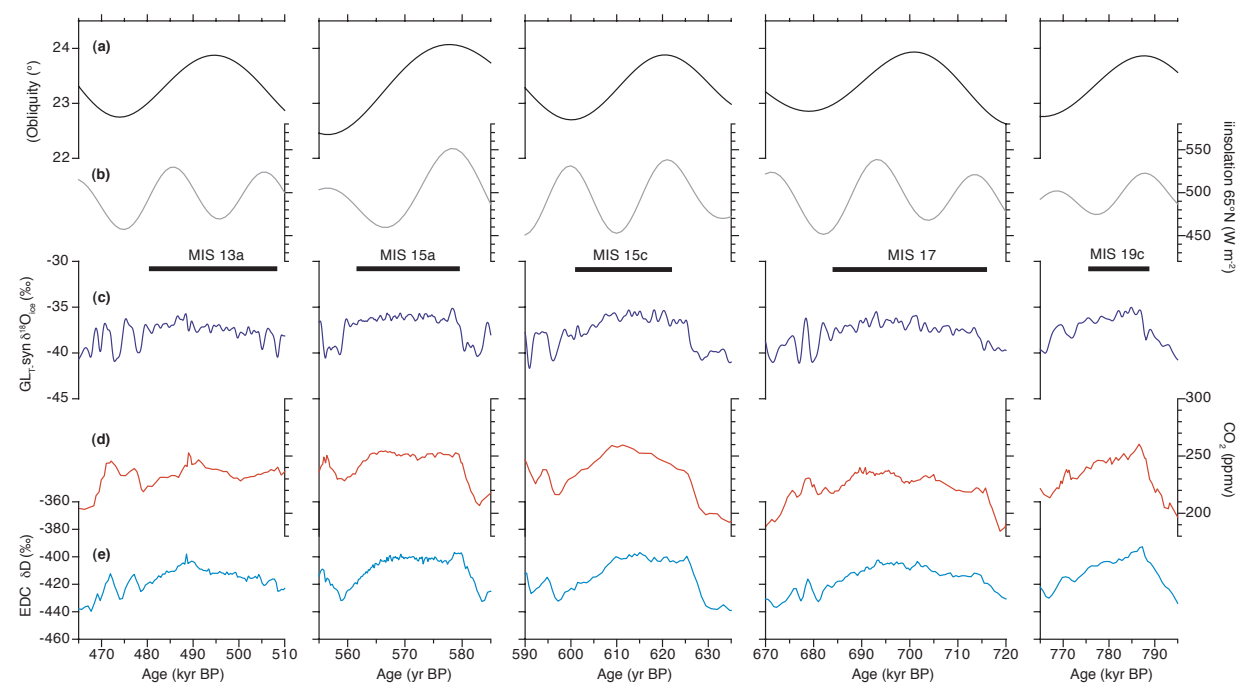

Fig. 4. Astronomical parameters and palaeoclimatic records for the interglacials corresponding to MIS 13a, 15a, 15c, 17 and 19c. Thick horizontal bands indicate estimated interglacial duration (see text). The onset of MIS $15 \mathrm{c}$ is placed at the second jump in the GL ${ }_{T-}$ syn record (621 kyr BP), rather than the first (626 kyr BP) on the basis of comparisons with isotopic and IRD records from the North Atlantic (Hodell et al., 2008), showing that 626-621 kyr BP is a complex deglaciation interval, with the terminal Heinrich event occurring at $621 \mathrm{kyr}$ BP. (a) obliquity (Laskar et al., 2004); (b) daily mean insolation at the summer solstice (21 June) at $65^{\circ} \mathrm{N}$ (Laskar et al., 2004); (c) Reconstructed $\delta^{18} \mathrm{O}$ composition of ice in Greenland synthetic (GL $\mathrm{G}_{-}$syn) record (Barker et al., 2011); (d) atmospheric $\mathrm{CO}_{2}$ concentration in Antarctic ice cores (Lüthi et al., 2008); (e) $\delta$ D composition of ice in the EDC ice core (Jouzel et al., 2007). Palaeoclimatic records are plotted on the EDC3 timescale of Parrenin et al. (2007).

important constraints on climate boundary conditions. While extending this investigation into the 41-kyr world of the Early Pleistocene is also desirable, the limited information on key climatic indices makes this task difficult at present. Following Tzedakis et al. (2009), the most prominent temperate sub-Stage within each odd-numbered Marine Isotope Stage of the benthic LR04 stack (Lisiecki and Raymo, 2005) is assigned an interglacial status (in MIS 15, both temperate sub-Stages $15 \mathrm{a}$ and $15 \mathrm{c}$ appear to be equally prominent). The occurrence of the bipolar seesaw may be inferred from the asynchronous phasing between $\mathrm{CH}_{4}$ concentrations (as a surrogate of Northern Hemisphere changes) and Antarctic temperatures in the EPICA Dome C (EDC) ice core (Jouzel et al., 2007; Loulergue et al., 2008), although the $\mathrm{CH}_{4}$ record may occasionally not record all events as clearly as North Atlantic records (e.g. subdued $\mathrm{CH}_{4}$ variations during Greenland Interstadials GI 19 and 20). Here we identify the occurrence of abrupt events on a new synthetic Greenland $\left(\mathrm{GL}_{T-}\right.$ syn) record, constructed from the $\mathrm{EDC} \delta \mathrm{D}$ record based on the bipolar-seesaw model (Barker et al., 2011). Although this is an indirectly-reconstructed Greenland temperature analogue, its comparison with highly-resolved $\delta^{18} \mathrm{O}$ planktonic and pollen records of millennial-scale variability from the Portuguese margin that extend beyond the Last Interglacial (e.g. Margari et al., 2010) has shown a close similarity. Where available, the identification of the bipolar seesaw may be corroborated by marine records from the Portuguese margin (Tzedakis et al., 2004; de Abreu et al., 2005), the central North Atlantic (Hodell et al., 2008) and the Gardar Drift (Channel et al., 2010; Tzedakis et al., 2012), showing asymmetric changes in their benthic-planktonic $\delta^{18} \mathrm{O}$ signals and occurrence of ice rafted detritus. The main advantage

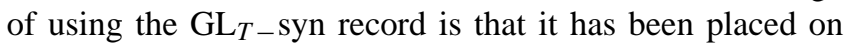
an absolute timeframe by alignment to precisely-dated Chinese speleothem records for the interval $0-400 \mathrm{kyr} \mathrm{BP}$. Before $400 \mathrm{kyr} B P$, the $\mathrm{GL}_{T-}$ syn record uses the EDC 3 chronology (Parrenin et al., 2007).

\section{Emerging patterns}

\subsection{Glacial inception}

Figure 5 shows that the onset of interglacials occurs within $2 \mathrm{kyr}$ of the boreal summer insolation maximum/precession minimum. The end of interglacials, however, does not fall consistently on the same part of the insolation curve, which suggests that the factors responsible for glacial inception are more diverse and potentially "non-stationary". Climate modelling studies show that a reduction in boreal summer insolation is the primary trigger for glacial inception, with $\mathrm{CO}_{2}$ playing a secondary role (Vettoretti and Peltier, 2004; Calov et al., 2009); reducing (increasing) $\mathrm{CO}_{2}$ concentrations shifts the inception threshold to higher (lower) insolation values (Berger et al., 1998; Archer and Ganopolski, 2005). A number of feedbacks and mechanisms (snow-albedo, ocean dynamics, equator-to-pole moisture transport, sea-ice-albedo, 


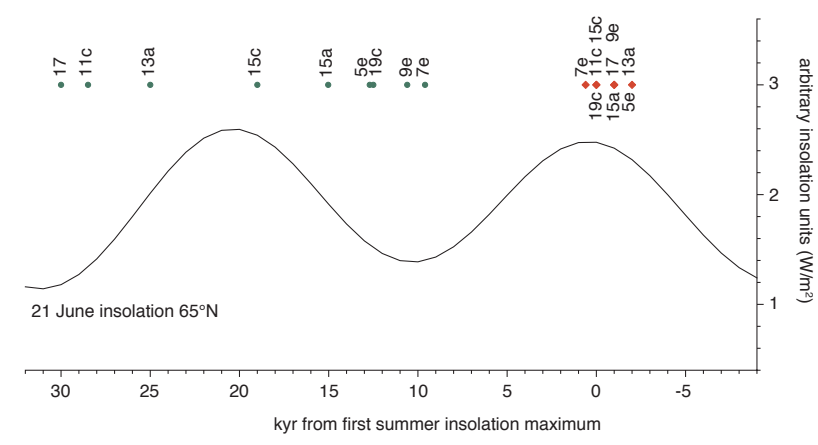

Fig. 5. Timing of the onset (diamonds) and end (circles) of interglacials in relation to an idealized 21 June at $65^{\circ} \mathrm{N}$ insolation curve.

forest-albedo) combine synergistically to amplify glacial inception (e.g. Khodri et al., 2001; Crucifix and Loutre, 2002; Vettoretti and Peltier, 2004; Calov et al., 2005). Below, we consider each inception in detail in relation to astronomical and $\mathrm{CO}_{2}$ changes (Figs. 3 and 4).

MIS 5e: glacial inception (114 kyr BP) occurred near the insolation minimum (116 kyr BP) and obliquity minimum (112 kyr BP). The large decline in summer insolation $\left(110 \mathrm{~W} \mathrm{~m}^{-2}\right)$ and associated feedbacks during MIS 5e appear to have been sufficient to lead to inception, despite the relatively high $\mathrm{CO}_{2}$ concentrations of $256 \pm 3$ ppmv.

MIS 7e: a large decline in summer insolation $\left(92 \mathrm{~W} \mathrm{~m}^{-2}\right)$ coupled with a considerable drop in $\mathrm{CO}_{2}$ concentrations to $244.5 \pm 0.5 \mathrm{ppmv}$ led to an early glacial inception at $\sim$ $234 \mathrm{kyr} \mathrm{BP}$ and one of the most extensive glaciations (MIS 7d) within an interglacial complex (e.g. Ruddiman and McIntyre, 1982). The short interglacial duration (9 kyr) is likely a result of the strong eccentricity-precession variations and the occurrence of the obliquity minimum $(232 \mathrm{kyr} \mathrm{BP})$ near the insolation minimum (231 kyr BP).

MIS 9e: glacial inception $(\sim 323 \mathrm{kyr} \mathrm{BP})$ occurred at the summer insolation minimum (323 kyr BP), $\sim 9 \mathrm{kyr}$ ahead of the obliquity minimum. Insolation and $\mathrm{CO}_{2}$ declined by $78 \mathrm{~W} \mathrm{~m}^{-2}$ (to $463 \mathrm{~W} \mathrm{~m}^{-2}$ ) and $43 \mathrm{ppmv}$ (to $256 \pm 3 \mathrm{ppmv}$ ), respectively.

MIS 11c: interglacial values persisted over two insolation peaks. Glacial inception occurred at the time of the summer insolation minimum $\sim 398 \mathrm{kyr} \mathrm{BP}$, according to the speleothem $\mathrm{GL}_{T-\text { syn timescale. This is } \sim 5 \mathrm{kyr} \text { earlier than }}$ in the EDC3 timescale, but in agreement with the Dome Fuji ice core chronology, based on astronomical tuning of the $\mathrm{O}_{2} / \mathrm{N}_{2}$ ratio of trapped air to local insolation (Kawamura et al., 2007, 2008), implying that the EDC3 ages over this interval may be too young. Atmospheric $\mathrm{CO}_{2}$ concentrations at inception remained high (259-265 ppmv), but summer insolation had decreased to $466 \mathrm{~W} \mathrm{~m}^{-2}$ and obliquity was reaching its minimum value at $394 \mathrm{kyr}$ BP.

MIS 13a: interglacial values persisted over two insolation peaks. Glacial inception occurred at $\sim 481 \mathrm{kyr} B P$, when summer insolation was relatively high at $500 \mathrm{~W} \mathrm{~m}^{-2}$, but

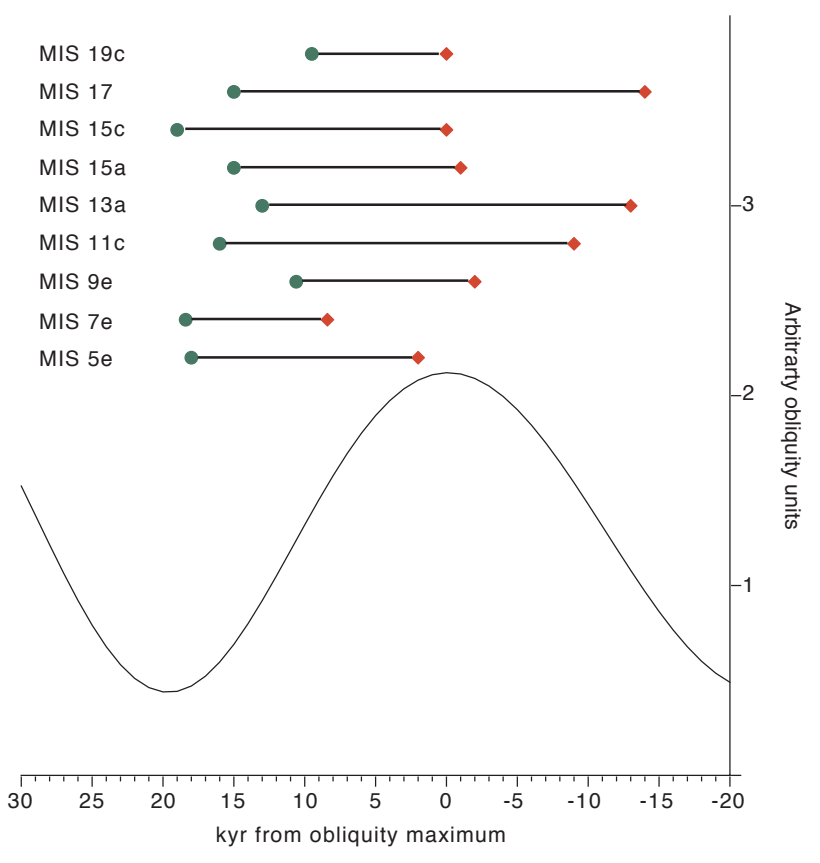

Fig. 6. Timing of the onset (diamonds) and end (circles) of interglacials in relation to an idealized obliquity curve.

$\mathrm{CO}_{2}$ concentrations had dropped to $225 \pm 2$ ppmv. Glacial inception appears to have taken place well ahead of the minimum in summer insolation ( $475 \mathrm{kyr} \mathrm{BP})$ and the minimum in obliquity (474 kyr BP) and there is some support for this from speleothem records in the Sanbao Cave, China (Cheng et al., 2012).

MIS 15a: glacial inception occurred at $\sim 562 \mathrm{kyr} \mathrm{BP}$, when summer insolation was $480 \mathrm{~W} \mathrm{~m}^{-2}$ and $\mathrm{CO}_{2}$ concentrations $240 \pm 5$ ppmv. The timing of inception post-dates the insolation minimum by $5 \mathrm{kyr}$ and pre-dates the obliquity minimum by 5 kyr. It should be noted that the duration of MIS 15 a has been considerably shortened in the EDC 3 timescale, which combines snow accumulation and mechanical flow model with independent age markers (Parrenin et al., 2007), relative to the earlier EDC2 chronology based only on iceflow modelling (EPICA community members, 2004). However, the onset of millennial-scale variability occurs $3 \mathrm{kyr}$ earlier in North Atlantic sequence U1308 (Hodell et al., 2008), which although within the absolute age uncertainty of $6 \mathrm{kyr}$ in EDC3, suggests that ice-flow irregularities may still be an issue in this part of the ice core.

MIS 15c: unlike other interglacials, glacial inception $\sim 601 \mathrm{kyr}$ BP occurred $9 \mathrm{kyr}$ after the summer insolation minimum, near the ensuing summer insolation maximum, which coincided with a minimum in obliquity. Unusually, atmospheric $\mathrm{CO}_{2}$ concentrations reached their peak values of $260 \mathrm{ppmv}$ at the time of the summer insolation minimum and then declined to $233 \pm 4$ ppmv by the time of the inception. Compared to EDC2, the revised EDC3 timescale has led to a longer MIS 15c, with the start and end of the interglacial 

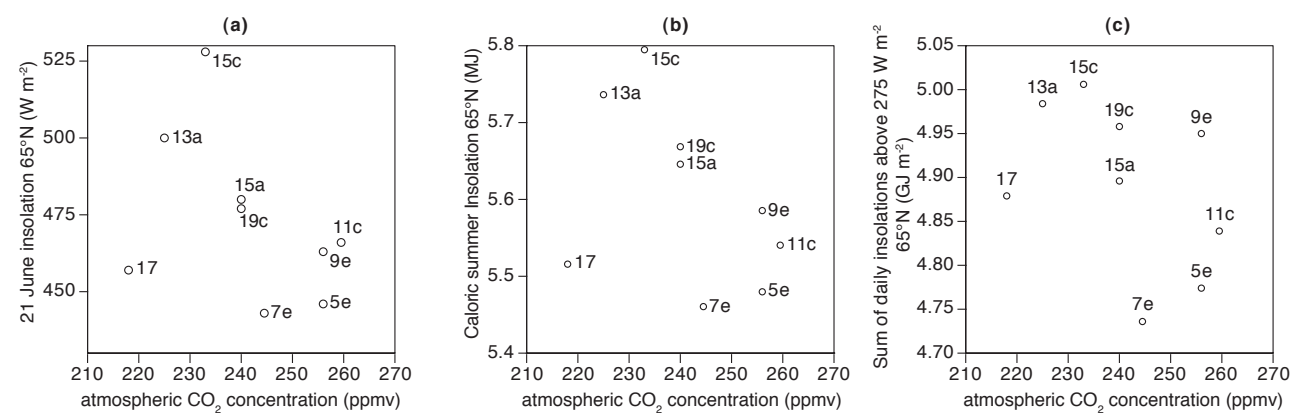

Fig. 7. Plot of atmospheric $\mathrm{CO}_{2}$ and boreal summer insolation values at the time of glacial inception. (a) $\mathrm{CO}_{2}$ concentration (Lüthi et al., 2008 ) versus daily mean insolation at the summer solstice (21 June) at $65^{\circ} \mathrm{N}$ (Laskar et al., 2004); (b) $\mathrm{CO}_{2}$ concentration (Lüthi et al., 2008) versus insolation at $65^{\circ} \mathrm{N}$ integrated over the caloric summer (the 180 days of highest insolation, assuming a 360-day year) (Milankovitch, 1941; Berger, 1978) (c) $\mathrm{CO}_{2}$ concentration (Lüthi et al., 2008) versus insolation at $65^{\circ} \mathrm{N}$ integrated over all days for which insolation exceeds $275 \mathrm{~W} \mathrm{~m}^{-2}$ (Huybers, 2006).

occurring earlier and later, respectively, though as in MIS $15 \mathrm{a}$, the effect of ice-flow irregularities may not have been entirely resolved. Again, comparison with U1308 (Hodell et al., 2008) suggests an earlier onset of millennial-scale variability by $3 \mathrm{kyr}$, which would shift the time of glacial inception to $604 \mathrm{kyr} \mathrm{BP}$.

MIS 17: interglacial values persisted over two insolation peaks. Glacial inception occurred at $\sim 684 \mathrm{kyr} \mathrm{BP,} 2 \mathrm{kyr}$ ahead of the summer insolation minimum and $5 \mathrm{kyr}$ ahead of the obliquity minimum. Insolation and $\mathrm{CO}_{2}$ values had dropped to $457 \mathrm{~W} \mathrm{~m}^{-2}$ and $218 \pm 1 \mathrm{ppmv}$, respectively.

MIS 19c: glacial inception at $\sim 775.5 \mathrm{kyr} \mathrm{BP}$ occurred near the insolation minimum at $777 \mathrm{kyr} \mathrm{BP}, \sim 10$ earlier than the obliquity minimum at $765 \mathrm{kyr} \mathrm{BP}$, in agreement with the identification of the onset of bipolar-seesaw variability in marine sequence ODP 983 in the North Atlantic (Channell, et al., 2010; Tzedakis et al., 2012). Summer insolation and $\mathrm{CO}_{2}$ values were $477 \mathrm{~W} \mathrm{~m}^{-2}$ and $240 \pm 5 \mathrm{ppmv}$, respectively.

The empirical evidence shows that of the nine glacial inceptions considered here (Fig. 5), five occurred over the descending limb of the 21 June at $65^{\circ} \mathrm{N}$ insolation curve (dominated by precession) or at its minimum. Three glacial inceptions (MIS 5e, 15a, 19c) occurred at a time of rising summer insolation, while that of MIS 15c appears to have occurred at the insolation maximum. All inceptions occurred over the descending limb of the obliquity curve and none after the obliquity minimum (Fig. 6). This lends support to climate modelling experiments that suggest that changes in obliquity dominate ice accumulation in high latitudes, while changes in the eccentricity-precession and $\mathrm{CO}_{2}$ radiative forcing have each about half the effect of the obliquity forcing (Vettoretti and Peltier, 2004). Examination of summer insolation and $\mathrm{CO}_{2}$ values at the nine inceptions (Fig. 7) reveals a weak negative trend: lower $\mathrm{CO}_{2}$ concentrations are encountered at higher insolation values, echoing modelling results (e.g. Berger et al., 1998; Archer and Ganopolski, 2005), although the spread in insolation values is large.

\subsection{Interglacial duration}

Estimates of interglacial length (Fig. 8, Table 1) suggest two main groups with mean duration of $13 \pm 3 \mathrm{kyr}$ and $28 \pm 2 \mathrm{kyr}$, respectively. More specifically, interglacials of the first group (MIS 5e, 7e, 9e, 15a and 19c) are characterized by early peaks in temperatures and greenhouse gas concentrations followed by monotonic declines (though not in MIS 15a). Interglacials of the second group (MIS 11c, 13a and 17) are characterized by slow deglaciation (Rohling et al., 2010; Ruddiman et al., 2011) and the persistence of interglacial values over two summer insolation peaks. The long duration of MIS $11 \mathrm{c}$ has been attributed to weak eccentricityprecession forcing, leading to a skipped precessional cycle, with obliquity becoming the dominant astronomical parameter driving ice volume changes (Masson-Delmotte et al., 2006). However, MIS 13a and 17 are not characterized by subdued eccentricity-precession variations, which suggests that their extended duration is a function of some other factor. This is further underlined by the short duration of MIS $19 \mathrm{c}$, despite its subdued amplitude of insolation changes, as a result of weak eccentricity-precession forcing (Tzedakis et al., 2012). One aspect common to MIS 11c, 13a and 17 is that precession and obliquity are nearly opposite in phase, with the obliquity maximum post-dating the first precession minimum by $11-13 \mathrm{kyr}$ and preceding the second precession minimum by $8-10 \mathrm{kyr}$. This means that the first summer insolation minimum occurred at the time of maximum obliquity. A low value of obliquity is important in determining ice accumulation in high latitudes, by leading to an intensified equator-to-pole insolation gradient and increased poleward transport of moisture, and by delaying the spring melt season (Raymo and Nisancioglu, 2003; Vettoretti and Peltier, 2004). In the absence of any significant decrease in $\mathrm{CO}_{2}$ concentrations (Figs. 3 and 4), the eccentricity-precession forcing alone would not have been sufficient to override the effect of maximum obliquity, leading to a skipped precessional 


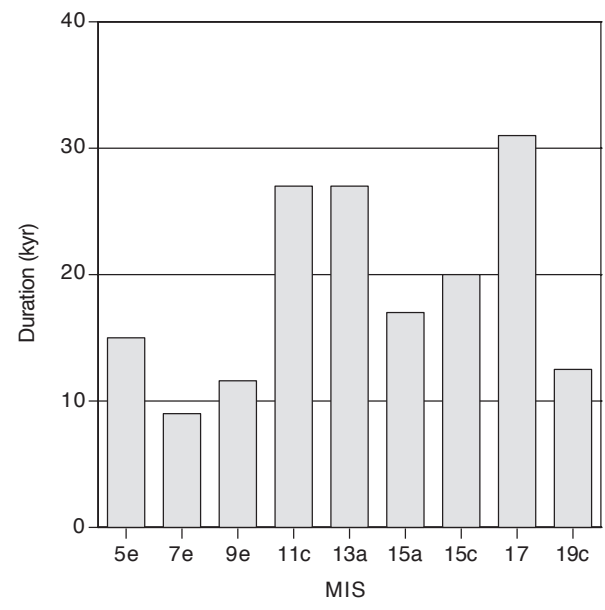

Fig. 8. Estimates of the duration of interglacials during the past 800 kyr. (a)

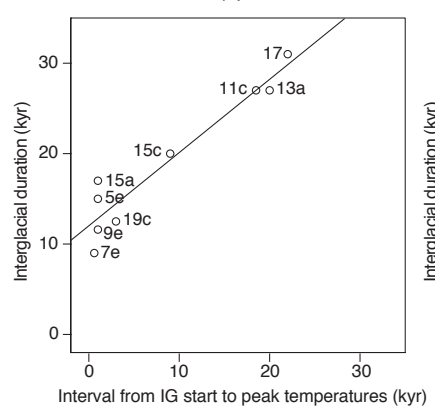

(b)

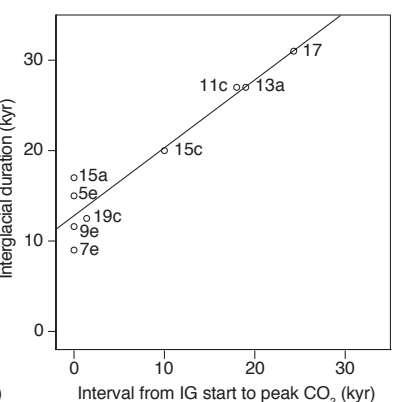

Fig. 9. Plot of the interval of time over which peak interglacial values are attained versus duration. (a) interval of time from inter-

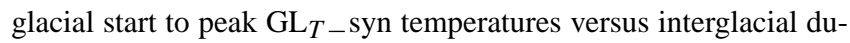
ration; (b) interval of time from interglacial start to peak $\mathrm{CO}_{2}$ concentrations versus interglacial duration. The regression lines $\left(R^{2}\right.$ 0.91 ) are essentially shifted from the $1: 1$ line by $\sim 10 \mathrm{kyr}$, representing an interglacial "relaxation" time back to glacial conditions.

beat and the persistence of interglacial values over an extended period.

MIS 15c stands apart, having an intermediate duration of $\sim 20 \mathrm{kyr}$ (assuming that the EDC3 chronology is not affected by ice-flow irregularities in that part of the core) and sharing some characteristics of both groups: precession and obliquity are in phase at its onset and the interglacial does not extend over two insolation cycles; on the other hand, Greenland temperatures peak late and $\mathrm{CO}_{2}$ concentrations rise gradually during the interglacial, reaching a maximum $11 \mathrm{kyr}$ into the interglacial. MIS $15 \mathrm{c}$ is characterized by a slow deglaciation with maximum sea level attained late in the interglacial (Ruddiman et al., 2011), in parallel with the $\mathrm{CO}_{2}$ evolution.

The interval of time over which peak temperature and $\mathrm{CO}_{2}$ values are attained is related to interglacial duration (Fig. 9): the longest interglacials (MIS 11c, 13a, 17) extend
Table 1. Timing of the onset and end of interglacials of the last $800 \mathrm{kyr}$ and their estimated duration.

\begin{tabular}{lrrr}
\hline MIS & $\begin{array}{r}\text { Onset } \\
\text { kyr BP }\end{array}$ & $\begin{array}{r}\text { End } \\
\text { kyr BP }\end{array}$ & $\begin{array}{r}\text { Duration } \\
\text { kyr }\end{array}$ \\
\hline $5 \mathrm{e}$ & 129 & 114 & 15 \\
$7 \mathrm{e}$ & 242.6 & 233.6 & 9 \\
$9 \mathrm{e}$ & 335 & 323.4 & 11.6 \\
$11 \mathrm{c}$ & 425 & 398 & 27 \\
$13 \mathrm{a}$ & 508 & 481 & 27 \\
$15 \mathrm{a}$ & 579 & $562^{*}$ & $17^{*}$ \\
$15 \mathrm{c}$ & 621 & $601^{*}$ & $20^{*}$ \\
17 & 715 & 684 & 31 \\
$19 \mathrm{c}$ & 788 & 775.5 & 12.5 \\
\hline
\end{tabular}

* The EDC3 chronology, which forms the basis for the age of these events, may be affected by ice-flow irregularities in that part of the EDC ice core, which in turn influences the estimated duration of these interglacials (see text).

into a second higher insolation peak, where maximum interglacial Greenland temperatures and $\mathrm{CO}_{2}$ values are reached. By comparison, maximum temperature and $\mathrm{CO}_{2}$ values are encountered at the start of the short interglacials (MIS 5e, 7e, 9e, 19c). The strong correlations shown in Fig. 9 point to a characteristic timescale of interglacial decline of $10 \pm 3$ kyr and $10.5 \pm 3.5 \mathrm{kyr}$ after peak Greenland temperatures and $\mathrm{CO}_{2}$ concentrations, respectively. This interglacial decline may be seen as an aspect of the forcing or of internal dynamics (e.g. limit cycle such as carbonate compensation). MIS $15 \mathrm{c}$ represents one notable exception, where peak values were attained at the summer insolation minimum. Decreases in Antarctic temperature and $\mathrm{CO}_{2}$ took place over the rising limb of the insolation curve, which may point to the overriding influence of obliquity reaching its minimum during the same time, or alternatively to inaccuracies in the EDC3 timescale.

Figure 10 shows the $\mathrm{CO}_{2}$ and summer insolation values at the time of glacial inception in relation to interglacial duration. With respect to $\mathrm{CO}_{2}$ concentrations (Fig. 10a), the warmest interglacials, MIS 9e, 5e and 11c, appear to have similarly high $\mathrm{CO}_{2}$ values at inception, despite differences in duration. A linear pattern, however, emerges for the "cooler" (sensu Tzedakis et al., 2009) interglacials MIS 7e, 19c, 15a, 15c, 13a and 17, which show a decrease in $\mathrm{CO}_{2}$ inception values as interglacial duration increases. It is interesting to note that the ordering of these cooler interglacials reflects differences in their relative interglacial intensities on the basis of their peak values in Antarctic temperatures and $\mathrm{CO}_{2}$ concentrations (Fig. 11), such that the coolest interglacial MIS 17 is also the longest. This initially appears somewhat counterintuitive, as one might have expected the coolest interglacials to glaciate faster, but it may be related to the effect of lower interglacial temperatures on precipitation: the hydrological cycle is less active when temperature decreases 

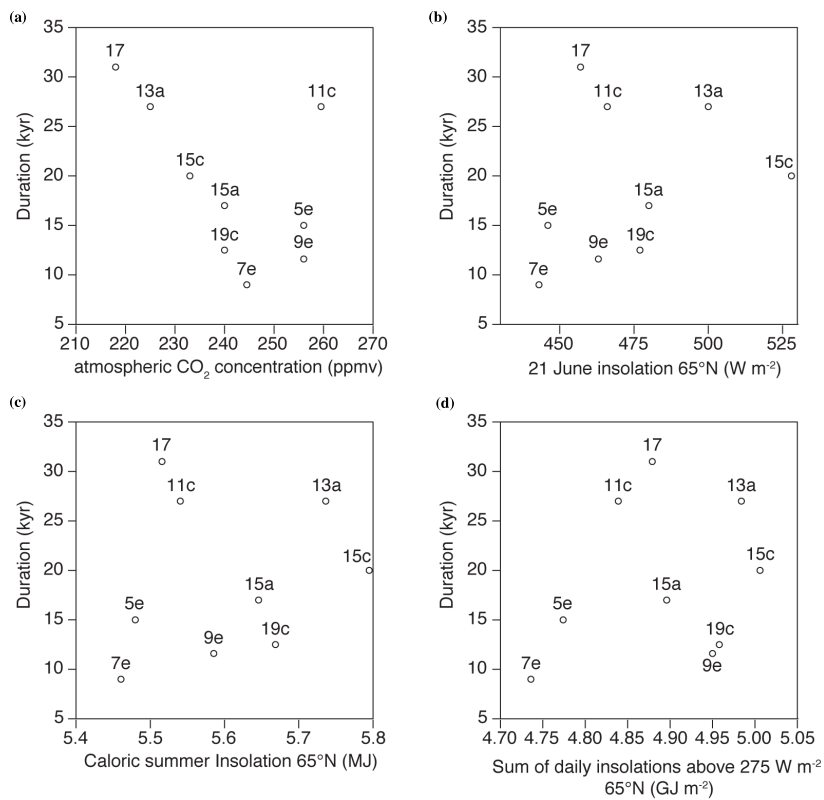

Fig. 10. Plot of atmospheric $\mathrm{CO}_{2}$ and boreal summer insolation values at the time of glacial inception versus interglacial duration. (a) $\mathrm{CO}_{2}$ concentration at inception versus duration; (b) daily mean insolation at the summer solstice (21 June) at $65^{\circ} \mathrm{N}$ (Laskar et al., 2004) at inception versus interglacial duration; (c) insolation at $65^{\circ} \mathrm{N}$ integrated over the caloric summer (the 180 days of highest insolation, assuming a 360-day year) (Milankovitch, 1941; Berger, 1978) at inception versus duration; (d) insolation at $65^{\circ} \mathrm{N}$ integrated over all days for which insolation exceeds $275 \mathrm{~W} \mathrm{~m}^{-2}$ (Huybers, 2006) versus interglacial duration.

and lower snow accumulation could outweigh the effect of reduced ablation on ice sheet growth (e.g. Källén et al., 1979; Ghil and Le Treut, 1981; Ghil et al., 1987). Lower $\mathrm{CO}_{2}$ concentrations would therefore be required to trigger glacial inception and this may account for differences in relative interglacial duration, such as that between the 'double-peaked' interglacials MIS 13a and 17.

No clear pattern emerges with respect to summer insolation (daily mean insolation at the summer solstice, insolation integrated over the caloric summer and insolation integrated over all days for which insolation exceeds $275 \mathrm{~W} \mathrm{~m}^{-2}$ ) values at inception and interglacial duration (Fig. 10b, c, d). A weak negative trend may be discerned within the longer interglacials, but interglacials with similar durations (e.g. MIS 13a and 11c) had substantially different insolation values at glacial inception. The overall lack of pattern may be related to timescale inaccuracies, but it may also imply that the instantaneous value of insolation at inception is not the critical parameter controlling interglacial duration.

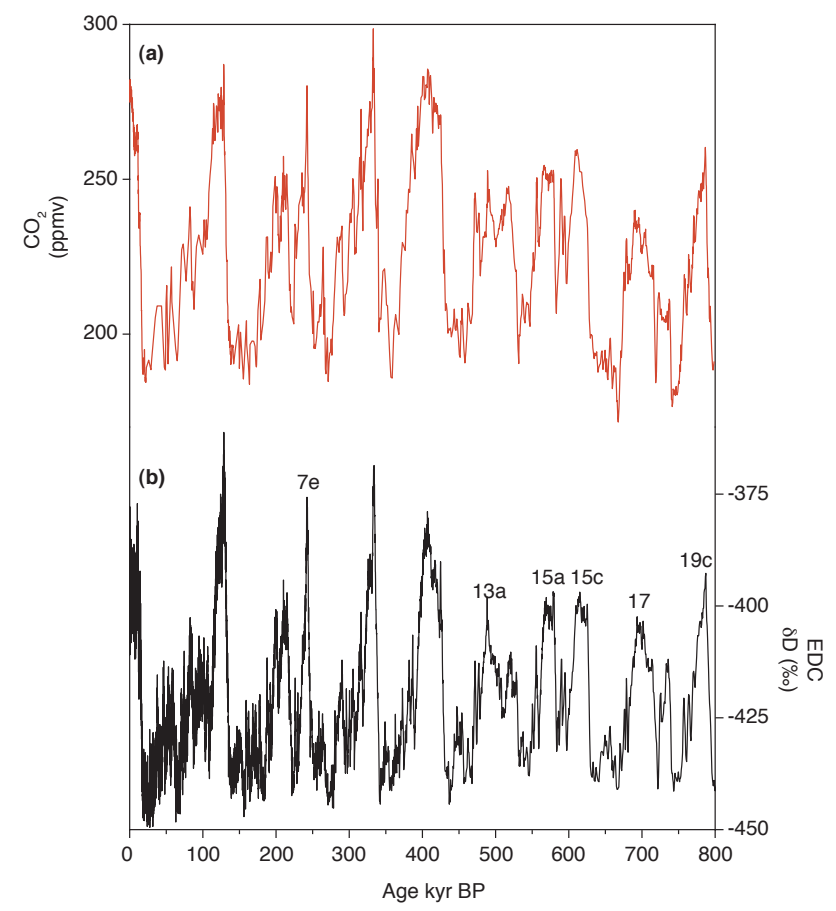

Fig. 11. Relative intensities of the "cooler" interglacials on the basis of their peak values in Antarctic temperatures and $\mathrm{CO}_{2}$ concentrations. (a) atmospheric $\mathrm{CO}_{2}$ concentration in Antarctic ice cores (Lüthi et al., 2008); (b) $\delta \mathrm{D}$ composition of ice in the EDC ice core (Jouzel et al., 2007). Records are plotted on the EDC3 timescale of Parrenin et al. (2007).

\section{Synthesis}

The start of interglacials is in line with the canonical view of Milankovitch forcing dictating the broad timing of interglacials (Milankovitch, 1941; Hays et al., 1976). More specifically, insolation/precession changes pace the timing of terminations, although the actual mechanisms controlling terminations may be related to the critical size of ice sheets and also to bipolar-seesaw variability and its influence on $\mathrm{CO}_{2}$ concentrations, combined with insolation forcing and ice-albedo feedbacks (e.g. Raymo, 1997; Paillard, 2001; Wolff et al., 2009; Denton et al., 2010; Barker et al., 2011). Glacial inception always takes place when obliquity is decreasing, but does not appear to be a simple function of the crossing of a specific threshold value in insolation (cf. Calder, 1974). Interglacials may be classified as either short (mean duration $\sim 13 \mathrm{kyr}$ ) or long (mean duration $\sim 28 \mathrm{kyr}$ ). The phasing of precession and obliquity appears to influence the persistence of interglacial conditions over one or two insolation peaks: the longest interglacials are characterized by the first summer insolation minimum occurring at the time of maximum obliquity, leading to a skipped precessional beat. Peak interglacial conditions are reached either early in the short interglacials or during the second insolation peak in the longer interglacials, with one exception (MIS 15c) when 


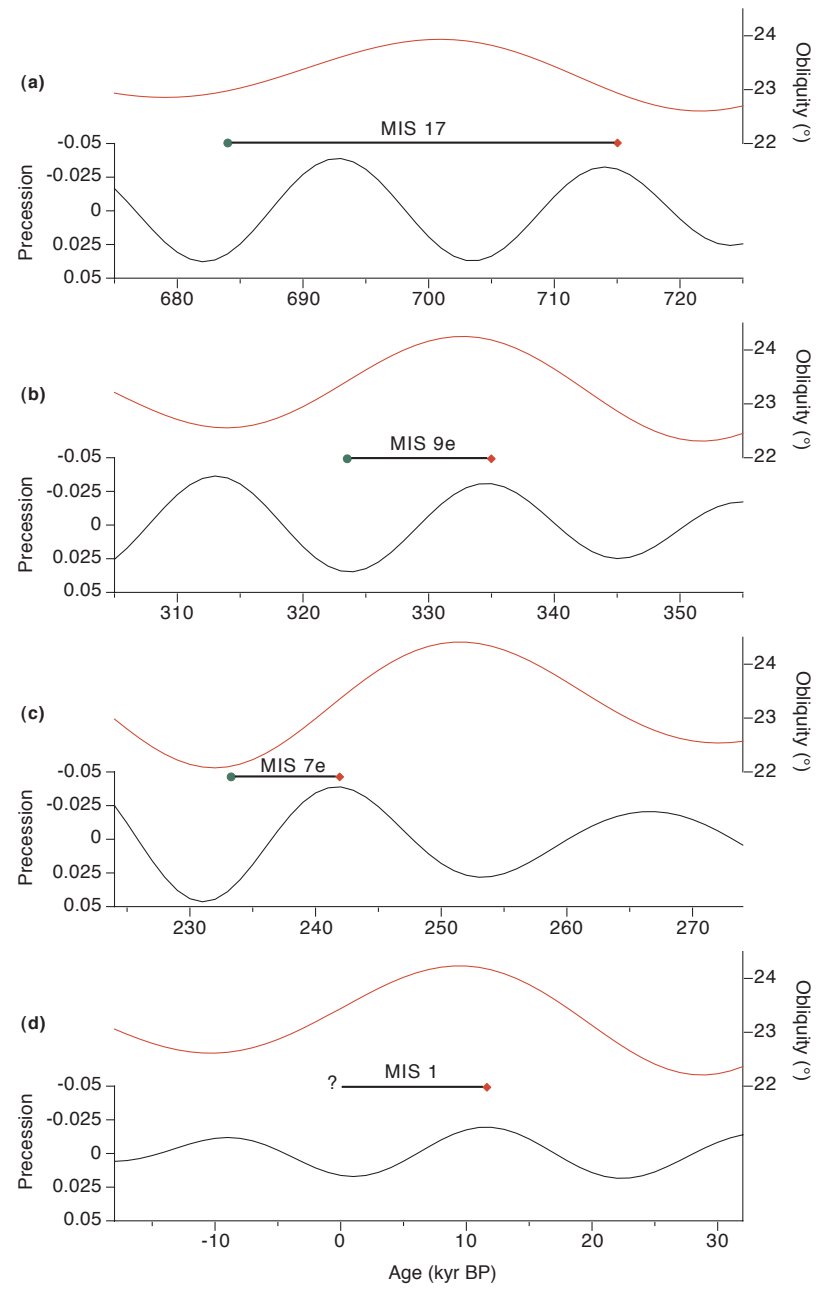

Fig. 12. Phasing of precession and obliquity (Laskar et al., 2004) in relation to interglacial duration (indicated by horizontal bars).

temperature and $\mathrm{CO}_{2}$ appear to have peaked near the summer insolation minimum. Glacial inception takes place approximately $10 \mathrm{kyr}$ after peak interglacial conditions, representing a characteristic timescale of interglacial decline.

These observations suggest that one may be able to predict the broad duration of an interglacial from its very outset. If the start of an interglacial and its associated insolation maximum/precession minimum occurs $9 \mathrm{kyr}$ or more before the obliquity maximum (Fig. 6), then we would expect a long interglacial which would register peak conditions during the second insolation maximum (MIS 11c, 13a, 17; Fig. 12a). If the start of an interglacial and its associated insolation maximum/precession minimum occurs near the peak in obliquity (Fig. 6), then an interglacial of approximately half a precession cycle would be expected (MIS 5e, 9e, 15a, 19c; Fig. 12b). Given that glacial inceptions do not occur over the ascending limb of the obliquity curve (Fig. 6), an even shorter duration would be expected if the interglacial starts well after (e.g. $8-9$ kyr) the obliquity peak (MIS 7e; Fig. 12c). MIS 15c is something of a conundrum in that the phasing of precession and obliquity would suggest an interglacial lasting about half a precession cycle, but its estimated duration is between long and short interglacials ( $\sim 20 \mathrm{kyr})$, with glacial inception occurring at the insolation maximum, which may imply that the EDC3 chronology is affected by ice-flow irregularities in that part of the core. A corollary of all this is that we should also be able to predict the duration of the current interglacial in the absence of anthropogenic interference. The phasing of precession and obliquity (precession minimum/insolation maximum at $11 \mathrm{kyr} \mathrm{BP}$; obliquity maximum at $10 \mathrm{kyr} \mathrm{BP}$ ) would point to a short duration, although it has been unclear whether the subdued current summer insolation minimum $\left(479 \mathrm{~W} \mathrm{~m}^{-2}\right)$, the lowest of the last $800 \mathrm{kyr}$, would be sufficient to lead to glaciation (e.g. Crucifix, 2011). Comparison with MIS 19c, a close astronomical analogue characterized by an equally weak summer insolation minimum $\left(474 \mathrm{~W} \mathrm{~m}^{-2}\right)$ and a smaller overall decrease from maximum summer solstice insolation values, suggests that glacial inception is possible despite the subdued insolation forcing, if $\mathrm{CO}_{2}$ concentrations were $240 \pm 5 \mathrm{ppmv}$ (Tzedakis et al., 2012).

Second-order differences in the relative timing of glacial inception within the same duration group (long and short interglacials) may be caused by chronological uncertainties and the simplistic assumption of a fixed lag between new ice growth and the onset of bipolar-seesaw variability. Small variations in climatic context of an interglacial and the magnitude of feedbacks may also have contributed to the divergence in the timing of glacial inception. For example, a negative precipitation-temperature feedback may be responsible for the greater interglacial duration associated with cooler interglacials.

While more precise chronologies are still required, especially for the interval 400-800 kyr BP, the systematic estimation of interglacial length represents a step towards the development of a theoretical framework to account for first-order differences in interglacial durations in the Middle and Late Pleistocene. Second-order differences may be more difficult to predict (why is MIS 5e longer than MIS 19c?), especially if stochasticity in the climate system and small variations in context and feedbacks lead to differences in the timing of inception. Although contextual differences (e.g. residual ice volume) may not be easy to reconstruct from proxy records especially for earlier interglacials, experiments with Earth System models may provide useful insights into their relative importance. In more general terms, the analysis presented here emphasizes the "memory" of the climate system, whose response to insolation forcing depends on the evolution of astronomical parameters and their integrated effects over time, rather than the instantaneous forcing strength. 
Acknowledgements. We are grateful to members of the Past Interglacials (PIGS) working group of the Past Global Changes (PAGES) project for discussions, especially Kenji Kawamura, Mark Maslin, Fréderic Parrenin and Bill Thompson. We thank two reviewers for their insightful comments and, in particular, Michel Crucifix for distilling the main points of the paper so succinctly. This is a contribution to the PAGES PIGS project. PCT acknowledges support from the UK Natural Environment Research Council.

Edited by: D. Fleitmann

\section{References}

American Commission on Stratigraphic Nomenclature: Code of stratigraphic nomenclature, Am. Assoc. Petr. Geol. B., 45, 645660, 1961.

Archer, D. and Ganopolski, A.: A movable trigger: Fossil fuel $\mathrm{CO}_{2}$ and the onset of the next glaciation, Geochem. Geophys. Geosyst. 6, Q05003, doi:10.1029/2004GC000891, 2005.

Bard, E., Hamelin, B., and Delanghe-Sabatier, D.: Deglacial meltwater Pulse 1B and Younger Dryas sea levels revisited with boreholes at Tahiti, Science, 327, 1235-1237, 2010.

Barker, S., Knorr, G., Edwards, L., Parrenin, F., Putnam, A. E., Skinner, L. C., Wolff, E., and Ziegler, M.: 800,000 years of abrupt climate variability, Science, 334, 347-351, 2011.

Berger, A.: Long-term variations of caloric insolation resulting from the earth's orbital elements, Quaternary Res., 9, 139-167, 1978.

Berger, A., Loutre, M. F., and Gallée, H.: Sensitivity of the LLN climate model to the astronomical and $\mathrm{CO}_{2}$ forcings over the last 200 ky, Clim. Dynam., 14, 615-629, 1998.

Bintanja, R. and van de Wal, R. S. W.: North American ice sheet dynamics and the onset of 100,000-year glacial cycles, Nature, 454, 869-872, 2008.

Calder, N.: Arithmetic of ice ages, Nature, 252, 216-218, 1974.

Calov, R., Ganopolski, A., Petoukhov, V., Claussen, M., Brovkin, V., and Kubatzki, C.: Transient simulation of the last glacial inception. Part II: sensitivity and feedback analysis, Clim. Dynam., 24, 563-576, 2005.

Calov, R., Ganopolski, A., Kubatzki, C., and Claussen, M.: Mechanisms and time scales of glacial inception simulated with an Earth system model of intermediate complexity, Clim. Past, 5, 245-258, doi:10.5194/cp-5-245-2009, 2009.

Capron, E., Landais, A., Lemieux-Dudon, B., Schilt, A., MassonDelmotte, V., Buiron, D., Chappellaz, J., Dahl-Jensen, D., Johnsen, S., Leuenberger, M., Loulergue, L., and Oerter, H.: Synchronising EDML and NorthGRIP ice cores using $\delta^{18} \mathrm{O}$ of atmospheric oxygen $\left(\delta^{18} \mathrm{O}_{\mathrm{atm}}\right)$ and $\mathrm{CH}_{4}$ measurements over MIS 5 (80-123 kyr), Quaternary Sci. Rev., 29, 222-234, 2010.

Channell, J. E. T., Hodell, D. A., Singer, B. S., and Xuan, C.: Reconciling astrochronological and ${ }^{40} \mathrm{Ar} /{ }^{39} \mathrm{Ar}$ ages for the MatuyamaBrunhes boundary and late Matuyama Chron, Geochem. Geophys. Geosyst., 11, Q0AA12, doi:10.1029/2010GC003203, 2010.

Chappell, J. and Shackleton, N. J.: Oxygen isotopes and sea level, Nature, 324, 137-140, 1986.

Cheng, H., Lawrence Edwards, R., Broecker, W. S., Denton, G. H., Kong, X., Wang, Y., Zhang, R., and Wang, X.: Ice Age Terminations, Science, 326, 248-252, 2009.
Cheng, H., Zhang, P. Z., Spötl, C., Edwards, R. L., Cai, Y. J., Zhang, D. Z., Sang, W. C., Tan, M., and An, Z. S.: The climatic cyclicity in semiarid-arid central Asia over the past 500,000 years, Geophys. Res. Lett., 39, L01705, doi:10.1029/2011GL050202, 2012

Crucifix, M.: How can a glacial inception be predicted?, The Holocene, 21, 831-842, 2011.

Crucifix, M. and Loutre, M. F.: Transient simulations over the last interglacial period (126-115 kyr BP): feedback and forcing analysis, Clim. Dynam., 19, 419-433, 2002.

de Abreu, L., Abrantes, F. F., Shackleton, N. J, Tzedakis, P. C., McManus, J. F., Oppo, D. W., and Hall, M. A.: Ocean climate variability in the eastern North Atlantic during interglacial marine isotope stage 11: A partial analogue to the Holocene?, Paleoceanography, 20, PA3009, doi:10.1029/2004PA001091, 2005.

Denton, G. H., Anderson, R. F., Toggweiler, J. R., Edwards, R. L., Schaefer, J. M., and Putnam, A. E.: The last glacial Termination, Science, 328, 1652-1656, 2010.

Drysdale, R. N., Zanchetta, G., Hellstrom, J. C., Fallick, A. E., McDonald, J., and Cartwright, I.: Stalagmite evidence for the precise timing of North Atlantic cold events during the early last glacial, Geology, 35, 77-80, 2007.

Ehlers, J. and Gibbard, P. L. (Eds.): Quaternary Glaciations - Extent and Chronology, Part I: Europe, Developments in Quaternary Science, 2a, Elsevier, Amsterdam, 2004.

Elderfield, H., Ferretti, G., Greaves, M., Crowhurst, S., McCave, I. N., Hodell, D., and Piotrowki, A. M.: Evolution of ocean temperature and ice volume through the Mid-Pleistocene climate transition, Science, 337, 704-709, 2012.

EPICA community members: Eight glacial cycles from an Antarctic ice core, Nature, 429, 623-628, doi:10.1038/nature02599, 2004.

Forsström, L.: Duration of interglacials: a controversial question, Quaternary Sci. Rev., 20, 1577-1586, 2001.

Ganopolski, A. and Rahmstorf, S.: Rapid changes of glacial climate simulated in a coupled climate model, Nature, 409, 153$158,2001$.

Ganopolski, A. and Roche, D.: On the nature of lead-lag relationships during glacial-interglacial climate transitions, Quaternary Sci. Rev., 37/38, 3361-3378, 2009.

Ghil, M. and Le Treut, H.: A climate model with cryodynamics and geodynamics, J. Geophys. Res., 86, 5262-5270, 1981.

Ghil, M., Mullhaupt, A., and Pestiaux, P.: Deep water formation and Quaternary glaciations, Clim. Dynam., 2, 1-10, 1987.

Green, C. L., Bigg, G. R., and Green, J. A. M.: Deep draft icebergs from the Barents ice sheet during MIS 6 are consistent with erosional evidence from the Lomonosov ridge, central Arctic, Geophys. Res. Lett., 37, L23606, doi:10.1029/2010GL045299, 2010.

Hays, J. D., Imbrie, I., and Shackleton, N. J.: Variations in the Earth's orbit: pacemaker of the ice ages, Science, 194, 11211131, 1976.

Hodell, D. A., Channell, J. E. T., Curtis, J. H., Romero, O. E., and Röhl, U.: Onset of "Hudson Strait" Heinrich events in the eastern North Atlantic at the end of the middle Pleistocene transition $(\sim 640 \mathrm{ka})$ ?, Paleoceanography, 23, PA4218, doi:10.1029/2008PA001591, 2008.

Hodell, D. A., Evans, H. F., Channell, J. E. T., and Curtis, J. H.: Phase relationships of North Atlantic ice rafted debris and surface sediment proxies during the last glacial period, Quaternary Sci. Rev., 29, 3875-3886, 2010. 
Huybers, P.: Early Pleistocene glacial cycles and the integrated summer insolation forcing, Science, 313, 508-511, 2006.

Jouzel, J., Masson-Demotte, V., Cattani, O., Dreyfus, G., Falourd, S., Hoffmann, G., Minster, B., Nouet, J., Barnola, J. M., Chappellaz, J., Fischer, H., Gallet, J. C., Johnsen, S., Leuenberger, M., Loulergue, L., Luethis, D., Oerter, H., Parrenin, F., Raisbeck, G., Raynaud., D., Schilt, A., Schwander, J., Selmo, E., Souchez, R., Spahni, R., Stauffer, B., Steffensen, J. P., Stenni, B., Stocker, T. F., Tison, J. L., Werner, M., and Wolff, E. W.: Orbital and millennial Antarctic climate variability over the past 800,000 years, Science, 317, 793-796, 2007.

Källén, E., Crafoord, C., and Ghil, M.: Free oscillations in a climate model with ice sheet dynamics, J. Atmos. Sci., 36, 2292-2303, 1979.

Kawamura, K., Parrenin, F., Lisiecki, L., Uemura, R., Vimeux, F., Severinghaus, J. P., Hutterli, M. A., Nakazawa, T., Aoki, S., Jouzel, J., Raymo, M. E., Matsumoto, K., Nakata, H., Motoyama, H., Fujita, S., Goto-Azuma, K., Fuji, Y., and Watanabe, O.: Northern Hemisphere forcing of climatic cycles in Antarctica over the past 360000 years, Nature, 448, 912-916, 2007.

Kawamura, K., Lisiecki, L., Raymo, M. E., Severinghaus, J. P., Matsushima, H., Aoki, S., and Nakazawa, T.: Precession pacing of 100-ky climatic cycles over the last $470 \mathrm{ky}$, Geophys. Res. Abstr., EGU2008-A-10602, EGU General Assembly 2008, Vienna, Austria, 2008.

Khodri, M., Leclainche, Y., Ramstein, G., Braconnot, P., Marti, O., and Cortijo, E.: Simulating the amplification of orbital forcing by ocean feedbacks in the last glaciation, Nature, 410, 570-574, 2001.

Kopp, R. E., Simons, F. J., Mitrovica, J. X., Maloof, A. C., and Oppenheimer, M.: Probabilistic assessment of sea level during the last interglacial stage, Nature, 462, 863-868, 2009.

Lambeck, K. and Chappell, J.: Sea level change through the last glacial cycle, Science, 292, 679-686, 2001.

Laskar, J., Robutel, P., Joutel, F., Gastineau, M., Correia, A. C. M., and Levrard, B.: A long term numerical solution for the insolation quantities of the Earth, Astron. Astrophys., 428, 261-286, 2004.

Lisiecki, L. E. and Raymo, M. E.: A Pliocene-Pleistocene stack of 57 globally distributed benthic $\delta^{18} \mathrm{O}$ records, Paleoceanography, 20, PA1003, doi:10.1029/2004PA001071, 2005.

Loulergue, L., Schilt, A., Spahni, R., Masson-Delmotte, V., Blunier, T., Lemieux, B., Barnola, J. M., Raynaud, D., Stocker, T. F., and Chappellaz, J.: Orbital and millennial-scale features of atmospheric $\mathrm{CH}_{4}$ over the past 800,000 years, Nature, 435, 383-386, 2008.

Lüthi, D., Le Floch, M., Bereiter, B., Blunier, T., Barnola, J. M., Siegenthaler, U., Raynaud, D., Jouzel, J., Fischer, H., Kawamura, K., and Stocker, T. F.: High-resolution carbon dioxide concentration record 650,000-800,000 years before present, Nature, 453, 379-382, 2008.

Margari, V., Skinner, L. C., Tzedakis, P. C., Ganopolski, A., Vautravers, M., and Shackleton, N. J.: The nature of millennialscale climate variability during the past two glacial periods, Nat. Geosci., 3, 127-133, 2010.

Masson-Delmotte, V., Dreyfus, G., Braconnot, P., Johnsen, S., Jouzel, J., Kageyama, M., Landais, A., Loutre, M.-F., Nouet, J., Parrenin, F., Raynaud, D., Stenni, B., and Tuenter, E.: Past temperature reconstructions from deep ice cores: relevance for future climate change, Clim. Past, 2, 145-165, doi:10.5194/cp-2-1452006, 2006.

Milankovitch, M.: Kanon der Erdbestrahlung und seine Andwendung auf das Eiszeiten-problem, Royal Serbian Academy, Special Publication 132, Belgrade, 1941.

Mix, A. C. and Ruddiman, W. F.: Oxygen isotope analyses and Pleistocene ice volumes, Quaternary Res., 21, 1-20, 1984.

North Greenland Ice Core Project members: High-resolution record of Northern Hemisphere climate extending into the last interglacial period, Nature, 431, 147-151, 2004.

Oppo, D. W., McManus, J. F., and Cullen, J. L.: Evolution and demise of the Last Interglacial warmth in the subpolar North Atlantic, Quaternary Sci. Rev., 25, 3268-3277, 2006.

Paillard, D.: Glacial cycles: toward a new paradigm, Rev. Geophys., 39, 325-346, 2001.

Parrenin, F. and Paillard, D.: Amplitude and phase of glacial cycles from a conceptual model, Earth Planet. Sc. Lett., 214, 243-250, 2003.

Parrenin, F., Barnola, J.-M., Beer, J., Blunier, T., Castellano, E., Chappellaz, J., Dreyfus, G., Fischer, H., Fujita, S., Jouzel, J., Kawamura, K., Lemieux-Dudon, B., Loulergue, L., MassonDelmotte, V., Narcisi, B., Petit, J.-R., Raisbeck, G., Raynaud, D., Ruth, U., Schwander, J., Severi, M., Spahni, R., Steffensen, J. P., Svensson, A., Udisti, R., Waelbroeck, C., and Wolff, E.: The EDC3 chronology for the EPICA Dome C ice core, Clim. Past, 3, 485-497, doi:10.5194/cp-3-485-2007, 2007.

Raymo, M. E.: The timing of major climate terminations, Paleoceanography, 12, 577-585, 1997.

Raymo, M. E. and Nisancioglu, K.: The $41 \mathrm{kyr}$ world: Milankovitch's other unsolved mystery, Paleoceanography, 18, PA2011, doi:10.1029/2002PA000791, 2003.

Rohling, E. J., Grant, K., Bolshaw, M., Roberts, A. P., Siddall, M., Hemleben, Ch., and Kucera, M.: Antarctic temperature and global sea level closely coupled over the last five glacial cycles, Nat. Geosci., 2, 500-504, 2009.

Rohling, E. J., Braun, K., Grant, K., Kucera, M., Roberts, A. P., Siddall, M., and Trommer, G.: Comparison between Holocene and Marine Isotope Stage-11 sea-level histories, Earth Planet. Sc. Lett., 291, 97-105, 2010.

Ruddiman, W. F. and McIntyre, A.: Severity and speed of northern hemisphere glaciation pulses-the limiting case, Geol. Soc. Am. Bull., 93, 1273-1279, 1982.

Ruddiman, W. F., Kutzbach, J. E., and Vavrus, S. J.: Can natural or anthropogenic explanations of late-Holocene $\mathrm{CO}_{2}$ and $\mathrm{CH}_{4}$ increases be falsified?, The Holocene, 21, 865-879, 2011.

Shackleton, N. J.: The last interglacial in the marine and terrestrial records, Proc. R. Soc. Lon. Ser. B, 174, 135-154, 1969.

Shackleton, N. J., Hall, M. A., and Vincent, E.: Phase relationships between millennial-scale events 64,000-24,000 years ago, Paleoceanography, 15, 565-569, 2000.

Shackleton, N. J., Chapman, M., Sánchez-Goñi, M. F., Pailler, D., and Lancelot, Y.: The classic Marine Isotope Substage 5e, Quaternary Res., 58, 14-16, 2002.

Skinner, L. C. and Shackleton, N. J.: An Atlantic lead over Pacific deepwater change across Termination I: implications for the application of the Marine Isotope Stage stratigraphy, Quaternary Sci. Rev., 24, 571-580, 2005.

Skinner, L. C., Elderfield, H., and Hall, M.: Past and Future Changes of the Ocean's Meridional Overturning Circulation: Mechanisms 
and Impacts, edited by: Schmittner, A., Chiang, J., and Hemming, S. R., 197-208 (AGU Monograph), 2007.

Stocker, T. F. and Johnsen, S. J.: A minimum thermodynamic model for the bipolar seesaw, Paleoceanography, 18, PA1087, doi:10.1029/2003PA000920, 2003.

Thompson, W. G. and Goldstein, S. L.: A radiometric calibration of the SPECMAP timescale, Quaternary Sci. Rev., 25, 3207-3215, 2006.

Tzedakis, P. C., Roucoux, K. H., de Abreu, L., and Shackleton, N. J.: The duration of forest stages in southern Europe and interglacial climate variability, Science, 306, 2231-2235, 2004.

Tzedakis, P. C., Raynaud, D. R, McManus, J. F., Berger, A., Brovkin, V., and Kiefer, T.: Interglacial diversity, Nat. Geosci., 2, 751-755, 2009.
Tzedakis, P. C., Channell, J. E. T., Hodell, D. A., Kleiven, H. F., and Skinner, L. C.: Determining the natural length of the current interglacial, Nat. Geosci., 5, 138-141, 2012.

Vettoretti, G. and Peltier, W. R.: Sensitivity of glacial inception to orbital and greenhouse gas climate forcing, Quaternary Sci. Rev., 23, 499-519, 2004.

Wolff, E. W., Fischer, H., and Rothlisberger, R.: Glacial terminations as southern warmings without northern control, Nat. Geosci., 2, 206-209, 2009. 